\title{
Transmedya Uygulamalarında Yayılma Kanalları: Küresel Örnekler Üzerine Bir İnceleme ${ }^{1}$
}

\author{
Selçuk BAZARCl²
}

\begin{abstract}
Öz
Günümüzde bireylere tek bir iletişim kanalından ulaşmak markalar için birtakım zorlukları beraberinde getirmektedir. Özellikle güçlenen tüketici profili nedeniyle insanlara temas etmek ve ürün/hizmet tercihi konusunda iknayı sağlamak için iletişim çalışmalarını şekillendirmek önemlidir. Bu noktada markaların tüketicilere ulaşmalarında ve iletişim çabalarını çeşitlendirmede kullandıkları alternatif çabalardan biri transmedya hikaye anlatımıdır.

Transmedya hikaye anlatımı, bir kurgunun ayrılmaz unsurlarının, birleşik ve koordine bir eğlence deneyimi yaratmak amacıyla, çoklu dağıtım kanallarına sistematik olarak dağıldığı bir süreci temsil etmektedir. Bu süreç, çoklu platformlara uygun olarak üretilen öykünün kendine özgü dinamiklerini ve sistemli bir içeriği bünyesinde barındırmaktadır. Bu bakımdan transmedya kampanyalarında geleneksel yöntemlerin aksine tek boyutluluk yerine her bir parçanın kendi deneyim özelliğini yansıttığı bir süreçten bahsetmek mümkündür.

Bu çalışmada transmedya kavramı ana hatlarıyla ele alınmaktadır. Pazarlama iletişiminde yaşanan evrim ve transmedyanın bu değişim içerisindeki durumunu ortaya koymak amacıyla dünya çapında kabul gören önemli transmedya örnekleri (Matrix, Harry Potter ve Star Wars) Henry Jenkins'in (2009) transmedya hikaye anlatımındaki yedi prensibine göre incelenmiştir. Elde edilen verilere bakıldığında parça özellikleri açısından her içeriğin orijinal bir özellik sunduğu ve temelde öze bağlı kalarak ana hikayeyi güçlendirmeye yönelik olarak tasarlandığı tespit edilmiştir.
\end{abstract}

Anahtar Kelimeler: Dijital iletişim, Pazarlama iletişimi, Transmedya.

Atıf: Bazarcı, S. (2019). “Transmedya Uygulamalarında Yayılma Kanalları: Küresel Örnekler Üzerine Bir İnceleme". Akdeniz Üniversitesi Iletișim Fakültesi Dergisi, (AKIL) Haziran (31), s. 560-576

1 Bu çalışma, 5. Uluslararası İletişim Öğrencileri Sempozyumu'nda (2018) bildiri olarak sunulmuştur.

2 Arş. Gör. Ege Üniversitesi İletişim Fakültesi, selcukbazarci@gmail.com Orcid ID: 0000-0003-0816-1362 


\title{
Dissemination Channels in Transmedia Study: A Research on Global Examples
}

\begin{abstract}
In today's digital world, reaching people via a single communication channel brings a number of challenges for brands. Particularly due to the strengthening consumer profile, it is important to contact people and to shape the communication practices to persuade them in terms of the choice of product/service. Transmedia storytelling is one of the alternative efforts of brands to reach consumers and diversify their communication efforts.

Transmedia storytelling represents a process in which the inseparable elements of a fiction are systematically distributed to multiple distribution channels in order to create a unified and coordinated entertainment experience. This process incorporates the unique dynamics and systematic content of the story produced in accordance with multiple platforms. In this respect, it is possible to talk about a process in which transmedia campaigns reflect the experience of each piece instead of one dimensionality rather than traditional ones.

In this study, the concept of transmedia is discussed. There is an evolution in marketing communication. In this context, it is important to define the state of transmission in this change. The most important examples of transmedia that accepted worldwide are examined accordance with the seven principles of transmedia storytelling (Jenkins, 2009). In terms of the characteristics of the pieces, each content presents an original feature. In addition, the contents are designed to strengthen the main story by abiding to the essence according to the seven principles.
\end{abstract}

Keywords: Digital communication, Marketing communication, Transmedia

\section{Giris}

T ransmedya hikaye anlatımı, bir hikayede her bir metnin bütüne katkısında çoklu medya platformları aracılığıyla nasıl ortaya çıktığı ve organize edildiğiyle ilgili süreçleri içermektedir. Çok platformlu hikaye anlatımı olarak da bilinen transmedya, bir tür kitle katılımı, etkileşim veya işbirliği içeren farklı medya türlerinde bir hikaye anlatmaktadır. İzleyicilerin medya içeriklerine dijital teknolojiler yoluyla etkileşimli bir dizge içerisinde katılabiliyor oluşu ortaya konan işin bir bütün olarak sunulmasını ve yayılabilirliğini mümkün kılmaktadır. Transmedya kavramı içeriğinde birçok farklı unsuru barındırmaktadır. Günümüzde çoklu medya kavramıyla eş anlamlı gibi görülse de transmedya hikaye anlatımının çoklu medyayı da içine alan bir yapıda evrildiği söylenebilir. Özellikle birden çok platformda uygulanması, metinlerarası olması, transmedyal anlatı ve transmedyal dünyaya yönelik içerik özelliklerini sunması 
transmedyayı tanımlayan temel unsurlardır (Fiorelli, 2013).

Transmedya hikaye anlatımında başarıya giden en önemli yollardan biri her bir aracın bağlı bulunduğu platformda güçlü yanlarını yansıtması ve çalışmaların buna göre şekillenmesidir. Bu bağlamda kitlelere ve mecralara yayılmak önemlidir. Çünkü doğru platformun tercihi ve koordine bir çalışmayla küresel bağlamda daha geniş ölçekte kitlelere erişebilmek mümkündür. Transmedya hikaye anlatımının sürdürülebilir bağlamda markaya birçok katkısı bulunmaktadır. Bunlardan biri yeni içerikleri tüketiciyle buluşturmasıdır. Değişen dünyada tüketicilerin medya yığınları içerisinde aynı ve tek kanal üzerinden aktarılan içeriklere talebi günden güne azalmaktadır. Bu nedenle markaların çalışmalarını çeşitlendirmesi ve hedef kitleye bağlı olarak doğru platformlarda çabalarını şekillendirmesi önemlidir.

Transmedya tek bir evrende yer alan birden fazla hikayeden oluşmaktadır. Her biri farklı medya biçimleriyle anlatılan ve böylece birbirini tamamlaması mümkün hale gelen transmedyada işleyişin nasıl olduğu ve anlatıyı çeşitlendirmede hangi özelliklerin etken olduğu önemlidir. Bu çalışmada önemli transmedya örnekleri olarak kabul edilen Matrix, Harry Potter ve Star Wars evrenleri Jenkins'in (2009) transmedya hikaye anlatımındaki yedi prensibine göre ele alınmıştır. Transmedya evrenlerini tanımlamak ve içerik özelliklerini derinlemesine irdelemek için araştırma deseni olarak nitel durum (örnek olay) çalışması tercih edilmiştir. Örnekleme dahil olan her evren yedi farklı kategori üzerinden ayrı ayrı değerlendirilerek anlamlandırılmaya çalışıımıştır.

\section{Transmedya Kavramına Genel Bir Bakıș}

Transmedya, 1990'lı yıllarda MIT profesörü Henry Jenkins tarafından ortaya atılan bir terimdir. Jenkins, her bir platformun genel bir hikayeye ayrılmaz bir katkıda bulunmasını sağlamak amacıyla, transmedya'yı çoklu medya platformlarında yayılma hikayesi olarak tanımlamıştır (Borden, 2010). İdeal olarak, her bir medya, hikayenin ortaya çıkmasına benzersiz bir katkı sağlamaktadır. Jenkins (2006: 22) transmedya kavramının çeşitliliğine vurgu yapmaktadır. Ona göre transmedya hikaye anlatımını anlamak için gereken tüm bilgileri elde edebilecek tek bir kaynak yerine çoklu kaynak aktarımının stratejik olarak ele alınması önemlidir.

Pratten'a (2011: 10) göre transmedya uygulamasını kurgulamak ve hayata geçirmek doğrusal bir süreçten ziyade yinelenen bir süreci içermektedir. Bu durum bazı varsayımlarla başlanan ve her geçişte arıtma, değiştirme ve iyileştirme yoluyla bir döngüye dönüşmektedir. Geliştirme döngüsünde altı temel bileşen bulunmaktadır (Bkz. Şekil 1). 


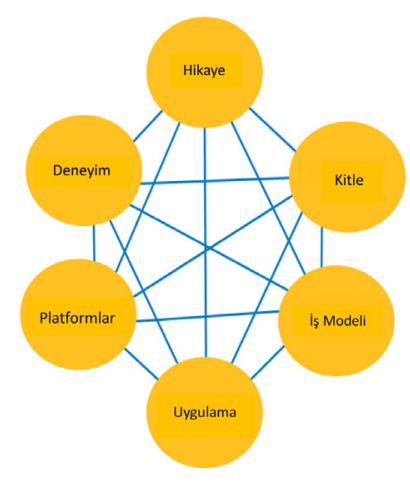

Şekil 1: Transmedya Gelişim Süreci

(Robert Pratten, "Getting Started in Transmedia Storytelling: A Practical Guide for Beginners" ISBN: 1456564684, http://videoturundus.ee/transmedia.pdf, 2011, s. 5)

Transmedya anlatımının başarılı ve koordineli bir biçimde yönetilmesi için bu altı bileşenin birlikte ve uyum içinde sürece entegre edilmesi gerekmektedir. Özellikle hikaye ve kullanıcı-izleyici deneyiminin uyumlu olması işlerin sürdürülebilir kılınmasında önemlidir. Aynı zamanda entegrasyonun etkin bir biçimde uygulanması adına doğru içeriğin doğru iletişim aracıyla doğru zamanda tüketiciye sunulması işlerin anlamlı olması açısından dikkate alınması gereken önemli bir unsurdur.

Transmedya anlatı anlayışını genişletecek şekilde gelişmeye devam edici unsurların sürdürülebilir kılınması önemlidir (Claebe ve Hancox, 2017). Uygulamada bağlantı noktalarını iyi belirlemek ve ana hikayeye temel ölçütlerde bağlı kalmak, çeşitlilik yaratmak için bir yol haritası oluşturulmasını sağlamaktadır. Bununla beraber transmedya hikaye anlatım formunda her bir medyaya uyum sağlayan içeriklerin hazırlanması ve hikaye örgüsünün medya yapısına uygun olarak tasarlanması gerekmektedir (Jenkins, 2003).

Transmedya, içerisinde komplike bir yapıyı barındıran ancak bu ağ örgüsünde stratejik bir sadelik taşıyan bir uygulama biçimidir. Bir transmedya şirketi olan Starlight Runner Entertainment'ın başkanı ve CEO'su Jeff Gomez, Avatar, Karayip Korsanları ve Ninja Kaplumbağalar gibi transmedya çalışmalarını yaparken bazı önemli hususlar üzerinde durmuştur. Ona göre başarılı bir transmedyanın sırrı, medya teknolojisini anlamak ve hikayenin her bir platform üzerindeki etkisini tanımlamakla ilgilidir. Gomez'e göre ilk adım, bir hikayeyi parçalarına ayırmaktan geçmektedir. Bu süreç, öyküde temaların (temel mesajlar), arketiplerin (karakterlerin nitelikleri) ve arzulayıcı bileşenlerin (anlatının en içsel arzularımızı nasıl ifade ettiği) belirlenmesini içerir. Diğer önemli unsurları şu şekilde özetlemek mümkündür (Bernstein, 2013, Roper, 2014, Escobedo, 2017):

- Transmedya kendi başına çok şey ifade etmemektedir. Çeşitli platformlarda bir bakıma anlamlı bir iletişimin gerçekleştirilmesine dayanır.

- Transmedya çalışmasında hikayeler üzerine bir kurgu söz konusudur. Tüm 
hikayeyi elde etmek için ise farklı medyalar üzerinden bir anlatım söz konusu olmaktadır. Yani hikayenin doğru anlaşılması ya da tamamlanabilmesi için medyanın uyumlu bir şekilde kullanılması önemlidir.

- Çok sayıda karakter içeren hikayeler, ekranın sınırlarının ötesine uzanan zengin bir yaşam sunmaktadır. Bu nedenle her bir hikayenin kendi içinde bir bütünlük barındırması gerekir.

- Hikayenin dünyası, gerçekliği hissettirmede son derece ayrıntılı olmalıdır. Ne kadar karmaşık olursa olsun temelde çıkış noktasını içeren konuların iletilmesi gerekir.

Gomez, yukarıda belirtilen tüm bu temel unsurların yanı sıra farklı değişkenlerin de dikkate alınması gerektiğini savunmaktadır. Bu bağlamda hikayeleri yaratmada ve doğru bir biçimde anlatmada tüketicilerin ne düşündüğünün analiz edilmesi önemlidir. Gomez tüketici profili ve transmedya yaratımı arasındaki ilişkiyi şu şekilde özetlemektedir (Bernstein, 2013):

"Çocukların ne yaptığına, gençlerin hikayeleri nasıl aldıklarına bakın. Bir şeyi sevdiklerinde daha fazlasını isterler ve tekrarlamak istemezler. Bir şeyi çok sevdiklerinde o içerikten daha fazlasını isterler, aynı şeyin tekrar etmesini değil! En popüler markalara bakıldığında çeşitli medya platformlarında hikayenin parçalarını anlattıklarını görmek mümkündür. Örneğin Star Wars ürettiği yeni video oyunlarının filmleri taklit etmeyeceğini, kendi yapısı içerisinde yeni ve özgün içeriklerle tüketiciye sunulacağını belirtmektedir. Bunun sebebi sorulduğunda marka üreticileri, filmlerin farklı bir üretim biçimini yarattığını, video oyunlarının kendi özgün içerikleriyle aslında yaratılan bu evreni geliştirmede kolaylıklar sunduğunu belirtmektedir. Bu noktada farklı transmedya uygulamaları Star Wars hayranları için etkileşimli deneyimler sunmada çok zengin bir hikaye dünyasını gerçek kılmaktadır".

Transmedya uygulamaları hedef kitle çeşitlemesi yaparak doğru tüketicilere doğru araçlarla ulaşabilme olanaklarını markalara sağlamaktadır. Özellikle değişen tüketici yapılanması markaların farklı uygulamalara yönelmesini ve çalışmalarında çeşitlilik sağlamasını teşvik eden bir duruma evrilmiştir. Bu noktada markaların sert rekabet koşullarında ayakta kalabilmeleri için hem üretim biçimlerini hem de iletişim faaliyetlerini kitlelerin yapısına göre çeşitlendirmesi gerekmektedir.

Transmedya çalışmalarında markaların her bir platform için farklı bir dil yaratması işleyiş sağlamada bazı kolaylıkları beraberinde getirmektedir. Bu bağlamda dijital teknolojiler kullanılarak farklı stratejilerin bir bütün halinde uygulanabilme intimalinden bahsetmek mümkündür. Dijital platformlar bir bütün olarak düşünüldüğünde dijital değişimlere uyumlu olarak internet teknolojileri, mobil teknolojiler ve tüm diğer dijital teknolojiler olarak değerlendirilmelidir (Kırcova ve Enginkaya, 2015: 15). Bu açıdan irdelendiğinde dijital ortamlarda gerçekleşen bu değişimi ve farklılaşmayı bir devrim olarak kabul etmek mümkündür. Toplumsal dönüşüme katkıda bulunan bu yeni devrim işletmelerin değişen koşullara ve hızlanan sisteme uyum sağlamalarını zorunlu kılmaktadır. 


\section{Medyanın Dijitalleșmesi ve Yakınsama}

Dijital medya ve uygulamalarını işler hale getiren ve etkin kılan ana unsur insandır. Hem kullanıcılar tarafından oluşturulan içerik hem de markaların tüketici etkileşimini destekleyen transmedya uygulamaları doğası gereği işbirliği ve katılımcı kültür özelliklerini taşımaktadır. Jenkins (2001: 93) bu durumu yakınsama kavramıyla ilişkilendirmiştir. Başlangıçta teknoloji temelli süreçler üzerine kurulan yakınsamayla medya ve iletişim teknolojileri, standart telefon, metin bağlantılı iletişim, e-posta ve internet tarayıcıları, sayısal video kameralar, video-müzik oynatıcılar ve oyun konsollarının özelliklerini içeren birleştirilmiş arabirimlerde ortaya çıkmaktadır (Ayten, 2014: 93). Kültürel anlamda gerçekleşen yakınsamayla birlikte çeşitli medya teknolojileri, endüstriler ve tüketiciler arasında internet bağlantılı yeni ilişkiler ve iletişim formları şekillenmektedir. Oluşan bu yeni ağ ile birlikte, bilgi akışkan ve etkin bir kimliğe bürünmekte; bilginin gücünün artması da toplumsal yapının değişmesine ve bu yapının elde edilen deneyimsel çıktılar noktasında evrilmesine neden olmaktadır (Jenkins, 2001: 93).

Bilgi iletişimteknolojilerindeyaşanangelişmelertoplumsal bağlamdadeğerlendirildiğinde bazı değişimleri beraberinde getirmiştir. Castells (2005: 8) teknolojideki bu değişimlerin toplumsal yapı üzerindeki etkisine vurgu yapmaktadır. Ona göre toplumların stratejik açıdan belirleyici olan bazı teknolojilere karşı kabiliyet özellikleri onların kaderlerini doğrudan etkilemektedir. Ayrıca Castells (2005: 9), var olan teknolojinin ya da yoksunluğun ortaya çıkardığı, kabullenme ve uygulama sürecinde oluşan kullanım tarzları ve toplumların bu süreçte kendilerini dönüştürme biçimlerinin tarihsel evrim ve toplumsal değişim üzerinde belirleyici bir role büründüğünü savunmaktadır.

Jenkins'in görüşleri de Castells'in ortaya attığı düşünce yapısını desteklemektedir. Jenkins (2001: 93) bilgi temelli değişimlerin toplumsal uzamlarını bu bağlamda incelemektedir. Toplumsal dinamiklerin farklılaşması tüketicilere temas etmek isteyen işletmelerin belirli bir dönüşüm geçirmesini gerekli kılmaktadır. Bu noktada yaşanan dijital dönüşümün markanın diğer iletişim faaliyetlerine nüfuz etmesi son derece normaldir.

Dijital medyadaki yakınsama teknolojideki gelişmelerle ilgilidir. Teknolojideki devrimle birlikte yerel, bölgesel, ulusal ve evrensel düzeyde yüksek hıza sahip büyük ölçekteki içeriklerin anlamları görülebilmektedir (Heesvelde, 2000: 273). Sosyo-ekonomik bağlamda incelendiğinde bu durumun en çok tüketiciler üzerinde etkisi olduğu söylenebilir. Dijital imkanların artması ve bireylerin internet tabanlı uygulamalar vasıtasıyla kolay yoldan iletişim kurabilmeleri herhangi bir haber veya olayın gerçek zamanlı olarak kitlelere aktarımını mümkün kılmaktadır. Bu nedenle farklı özellikteki araçların dijital medya üzerinden tek bir kanalda bir araya gelmesi bireylerin etkileşim kurmasını ve aynı zamanda içerik oluşturarak iletişim süreçlerine katılmasını kolaylaştırmaktadır. 


\section{Pazarlama Illetișiminde Transmedya Kullanımı}

İnternet teknolojileri, mobil teknolojiler ve benzer tüm teknolojilerin toplumlar üzerindeki etkisi düşünüldüğünde bilginin hayatın içine entegre olmasında dijital platformlar önemli bir araçtır. Dijital uygulamalar üzerinden bilginin aktarımıyla iletişimin yapısının da değiştiği söylenebilir. Özellikle dijital ortamlarda gerçekleşen değişim ve farklılaşma birçok alanda etkisini gösterdiği gibi pazarlama iletişiminde de birtakım dönüşümleri beraberinde getirmiştir.

Daha fazla izleyici katılımını teşvik etmeye yönelik olan ve kitlesel geri bildirimi tutarlı bir şekilde stratejiye dahil eden transmedya çabaları bu özelliğiyle geleneksel marka iletişim stratejilerinden ayrılmaktadır (Plessis, 2018: 4). Yaratılan bir kurgunun temel içeriklerini yansıtan transmedya, tüm unsurlarıyla birleşik ve koordine edilmiş bir eğlence alanı yaratmak için tasarlanmıştır. Bundan dolayı oluşturulan sürecin sistematik bir çerçevede organize edilmesi önemlidir.

Transmedya hikaye anlatımında oluşturulan içerik ve uygulama sadece bir ortamdan diğerine uyarlama şeklinde işlememektedir. Yaratılan farklı çalışmalar genişleyen özel bir hikaye yapısını ortaya çıkarmaktadır. Bu farkıı̆ı̆ı ortaya çıkaran birçok değişken bulunmaktadır. Örneğin metinsel yapıdaki farklılıklar nedeniyle çizgi romanların anlattığı hikayeyle televizyonda ya da sinemada anlatılanın aynı olması mümkün değildir (Plessis, 2018: 5). Bu nedenle farklı medya ve dillerin transmedya hikaye dünyasının inşasına katkıda bulunduğu söylenebilir.

Markalar açısından tüketici odaklı sosyal markalaşmada etkileşim sağlamak ve olumlu bir marka imajı yaratmak önemlidir. Bir etkileşim stratejisi olarak transmedya hikaye anlatımı, markanın sahip olduğu değerleri farklı yapılar üzerinden bütünleşik bir düzlemde aktarabilmesini sağlamaktadır. Tüketicinin de hikaye dünyasının bir parçasına dönüşebildiği transmedya çalışmalarında farklı yapılara ayrılmış olan öyküler katılımcıların parçaları birleştirmesiyle bir bütün haline dönüşmektedir. Burada önemli olan nokta her uygulamanın birbirinden farklı özellikte kurgulanmasında temelde tek bir bütün olarak ana yapıya uyumlu bir içerik özelliği taşıyor olmasıdır.

Farklı medyalarda anlatılan ve farklı hikayeleri içeren transmedya'da entegre bir deneyim yaratmak için var olan bir hikayenin değerlerinin tüm farklı metinler ve medyada aynı şekilde ifade edilmesi gerekmektedir (Brieger, 2013: 9). Her kurgusal dünya bir dizi farklı anlatı ve söylemsel özellik sunmaktadır (Scolari, 2009: 600). Bu nedenle marka için kimlik unsurlarının tüm parçalara doğru bir biçimde uyarlanmasının medya içeriğinin şekillenmesinde ve içerik etkinliğinin maksimize edilmesinde önemli olduğu söylenebilir. 


\section{Yöntem}

\subsection{Araștırmanın Problemi}

Transmedya hikaye anlatımı, bütünün birer parçası olarak her bir metnin ve uygulamanın ayrı bir katkı mekanizması yaratarak çoklu medya platformları aracılığıyla planlandığı ve sunulduğu durumları içermektedir. Karmaşık bir düzen içerisinde bütünsel unsurların aktarıldığı bu süreçte her detayın ve içerdiği katkıların anlamlandırılması önemlidir. Bu bağlamda transmedya hikaye anlatımında etken olan değişkenlerin neler olduğunun belirlenmesi ve parçayı oluşturan unsurların hangi dinamiklerden etkilendiğinin tanımlanması araştırma problemini oluşturmaktadır.

\subsection{Araștırmanın Amacı}

Bu çalışma kapsamında transmedya uygulamalarında parça ve bütün ilişkisi ortaya konarak Jenkins'in yedi prensibine göre içerikler değerlendirilmektedir. Bu prensiplere göre ilk tema olan yayılabilirlik-delinebilirlik başlığında anlamlı veri parçalarını bulmada yaygın medya ortamlarının taranması ve izleyicinin hikayede daha derine inme noktaları tanımlanmaktadır. Süreklilik-çokluluk temasında, hikayenin mantık çerçevesinde kurgulanış biçimi ve parçaların yapısal bütünlüğe katkısı ele alınmaktadır. Daldırma ve çıkartılabilirlikte gelişmiş sanal kurgular bağlamında tüketicilerin hikaye içine dahil edilme özellikleri ve gerçek dünyada karşılık bulma şekilleri irdelenmektedir. Dünya inşasında, bir önceki temayla bağlantılı olarak tüketicinin dahil olduğu kurgusal dünyada potansiyel etkileşim noktaları ve özellikleri tanımlanmaktadır. Dizisellik temasında bütünü oluşturan parçaların anlamlılıkları ve hikayeye olan katkıları irdelenmektedir. Öznellik kısmında, oluşturulan kurgusal dünyadaki keşfedilmemiş unsurlara odaklanılmaktadır. Son olarak performans temasında ise etkileşimli süreç kapsamında tüketicilerin hikaye bütününe yapmış oldukları katkılar değerlendirilmektedir. Bu bağlamda transmedya çalışmalarının derinlemesine incelenerek Jenkins'in ortaya attığı yedi temel ilkeye göre anlamlandırılması amaçlanmaktadır.

\subsection{Araștırmanın Örneklemi}

Çalışma kapsamında amaçlı örnekleme yöntemlerinden benzeşik (homojen) örnekleme tercih edilmiştir. Amaçlı örneklemede çoklu bilgiler içeren durumların derinlemesine ve kapsamlı olarak çalışılması söz konusudur. Bu bağlamda benzeşik örnekleme yöntemiyle belirgin bir alt grubun tanımlanması amaçlanmaktadır (Yıldırım ve Şimşek, 2013: 137). Araştırma doğrultusunda dünya çapında önemli örneklerden kabul edilen Matrix, Harry Potter ve Star Wars transmedya hikaye anlatımları çalışma örneklemi olarak belirlenmiştir.

\subsection{Araștırmanın Deseni}

Araştırma kapsamında transmedya uygulamalarını tanımlamak ve temel özellikleri üzerine derinlemesine anlamlandırma çalışması yapmak için durum (örnek olay) 
çalışması tercih edilmiştir. Nitel durum çalışmasında önemli unsurlardan biri belirli bir durumu derinlemesine irdelemektir. Her bir örneğin kendi dinamikleri içerisinde farklı oluşumları ve anlamları taşımasından dolayı çalışılan durumlar üzerinden bir genelleme yapma kaygısı bulunmamaktadır. Buna ek olarak benzer durumlar üzerinden bir anlamlandırma çabasının varlığından bahsetmek mümkündür. Duruma ilişkin etkenler olan ortam, birey, olay ve süreç gibi farklı bileşenler bütüncül bir anlayışla araştırılarak var olan durumu nasıl etkiledikleri ve ilgili durumdan nasıl etkilendikleri bu araştırma deseniyle ortaya konulmaktadır (Yıldırım ve Şimşek, 2013: 83).

\subsection{Bulgular ve Yorum}

\subsubsection{Matrix}

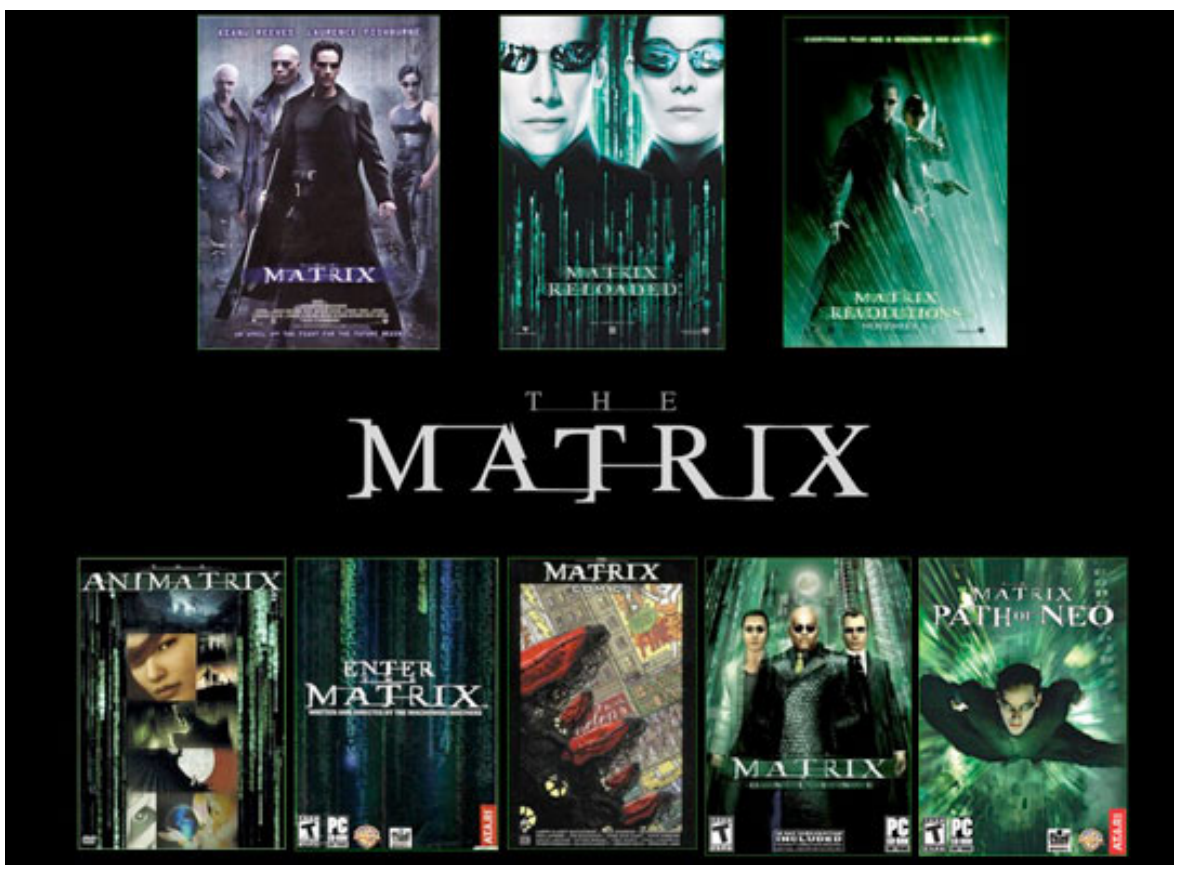

Görsel 1. Matrix Evreni

Günümüz toplumunda dijital iletişim platformlarının çoğalması, öykülerin anlatımında çeşitlilik imkanlarını sunmaktadır. Elektroniklerin, yazılımların ve internetin erişilebilirliği, insanların daha önce hiç olmadığı kadar öyküleri oluşturmak için kullanabilecekleri araçlara erişimini teşvik etmektedir. Bu dijital hikaye anlatımı, fotoğraf, video, animasyon, ses ve metin kullanarak yeni bir etkileşim kurmayı üzerine şekillenmektedir. Film, televizyon, video oyunları, kitaplar, çizgi romanlar ve internet gibi pek çok farklı platform ve formatta deneyim yaratan bir yöntem olan transmedya hikaye anlatımıyla dijital formatları kullanmanın bir yöntemi markalar tarafından değerlendirilmektedir. Matrix evreni, üç uzun metrajı canlı aksiyon filmi ile tanınsa da, hikaye ve karakterler diğer platformlar arasında bir animasyon filmi ve bir PC ve çevrimiçi oyuna uyarlanmıştır. 
Bu uyarlamalar sadece orijinal içeriğin basit bir şekilde düzeltilmesi değil, her bir çalışmanın özerklik düzeyini ve kendi bağımsız hikayesini gösteren, özellikle kendi ortamları için yaratılmışlardır (www.futurelearn.com).

Tablo 1. Matrix evreninin transmedya hikaye anlatımındaki yedi prensibe göre değerlendirilmesi

\begin{tabular}{|c|c|}
\hline $\begin{array}{l}\text { Yayılabilirlik ve } \\
\text { Delinebilirlik }\end{array}$ & $\begin{array}{l}\text { Matrix evreni izleyicinin derin bir deneyim kazanmasını ve işin } \\
\text { derinliklerine inebilmesini kolaylaş̧ıran bir özelliğe sahiptir. Farklı } \\
\text { uygulamalar arasında karmaşık bir yapının kurulması ve izleyicilerin bu } \\
\text { gizemli oluşumları çözmeye yönlendirilmesi bir yandan aktif toplulukların } \\
\text { kurulmasını sağlarken diğer yandan geniş bir kolektif anlayışı ortaya } \\
\text { çıkarmaktadır. }\end{array}$ \\
\hline $\begin{array}{l}\text { Süreklilik ve } \\
\text { Çokluluk }\end{array}$ & $\begin{array}{l}\text { Matrix transmedya uygulamaları parça özellikleri bağlamında kendi } \\
\text { içinde yapısal bir bütünlük taşımaktadır. Her içerik orijinal bir özellik } \\
\text { taşırken temelde çıkış noktası olarak öze bağlı kalmaktadır. Bunun yanı ı } \\
\text { sıra her bir parçanın sahip olduğu içeriğin kendi anlatım özelliklerine } \\
\text { dayandığı söylenebilir. }\end{array}$ \\
\hline $\begin{array}{l}\text { Daldırma ve } \\
\text { Çıkartılabilirlik }\end{array}$ & $\begin{array}{l}\text { Matrix dünyasındaki farklı uygulamalar kullanıcı deneyimini teşvik edici } \\
\text { bir özellikte kurgulanmıştır. Hikayenin tamamına entegre olabilmek } \\
\text { ve aktarılan hissi deneyimleyebilmek için derine dalmak önemlidir. } \\
\text { Örneğin filmde ana unsur olmayan Niobe ve Ghost gibi karakterlerin } \\
\text { video oyununda daha önemli rollere bürünmesi işleyişin farklı bir } \\
\text { derinlik sunmasına etken olmaktadır. Bu nedenle kullanııların anlaşı̧ır } \\
\text { özellikleri kavrayabilmesi için bu karakterlere yoğunlaşması önemlidir. }\end{array}$ \\
\hline Dünya İnşası & $\begin{array}{l}\text { Matrix'te kurgulanan karmaşıklığı destekleyen ve çözüme yönelik } \\
\text { parçaların serpiştirildiği bir yapı yansıtılmaktadır. Ortaya konan her parça } \\
\text { hikayeyi desteklemekte ve yeni bir anlayışın yaratımını sağlamaktadır. }\end{array}$ \\
\hline Dizisellik & $\begin{array}{l}\text { Hikaye dünyasının unsurları olan film üçlemesi, çizgi roman, video } \\
\text { oyunu ve animasyon uygulaması medyanın anlamlı ve koordineli bir } \\
\text { biçimde parçalanmasını temsil etmektedir. Örneğin hem animasyonda } \\
\text { hem de çizgi romanda bölümlere ayrılmış kısa hikayeler anlatılmasına } \\
\text { rağmen birbirleriyle bağlantı ve temelde bir bütünlük korunmaktadır. }\end{array}$ \\
\hline Öznellik & $\begin{array}{l}\text { Farklı uygulamalar üzerinden şekillenen Matrix evreni yaratılan kurgusal } \\
\text { dünyanın keşfedilmemiş farklı unsurlarını yansıtmaktadır. Tüketicilerin } \\
\text { diğer kurgularda ön planda olmayan karakterlerin sahip olduğu rolleri } \\
\text { tanımlamasında ve onlar hakkında yeni bir şeyler ortaya çıktıkça } \\
\text { bilinmeyen yanlarının belirmesi öznelliğe katkıda bulunan bir özellik } \\
\text { taşımaktadır. }\end{array}$ \\
\hline Performans & $\begin{array}{l}\text { Performans ilkesinde etkileşimli sürecin doğası gereği kullanıcıların } \\
\text { sürece dahil olması ve yeniden üretimde alternatif içerikleri yaratmaları } \\
\text { söz konusudur. Matrix'te de bu sürecin etkinliğinden bahsetmek } \\
\text { mümkündür. }\end{array}$ \\
\hline
\end{tabular}




\subsubsection{Harry Potter}

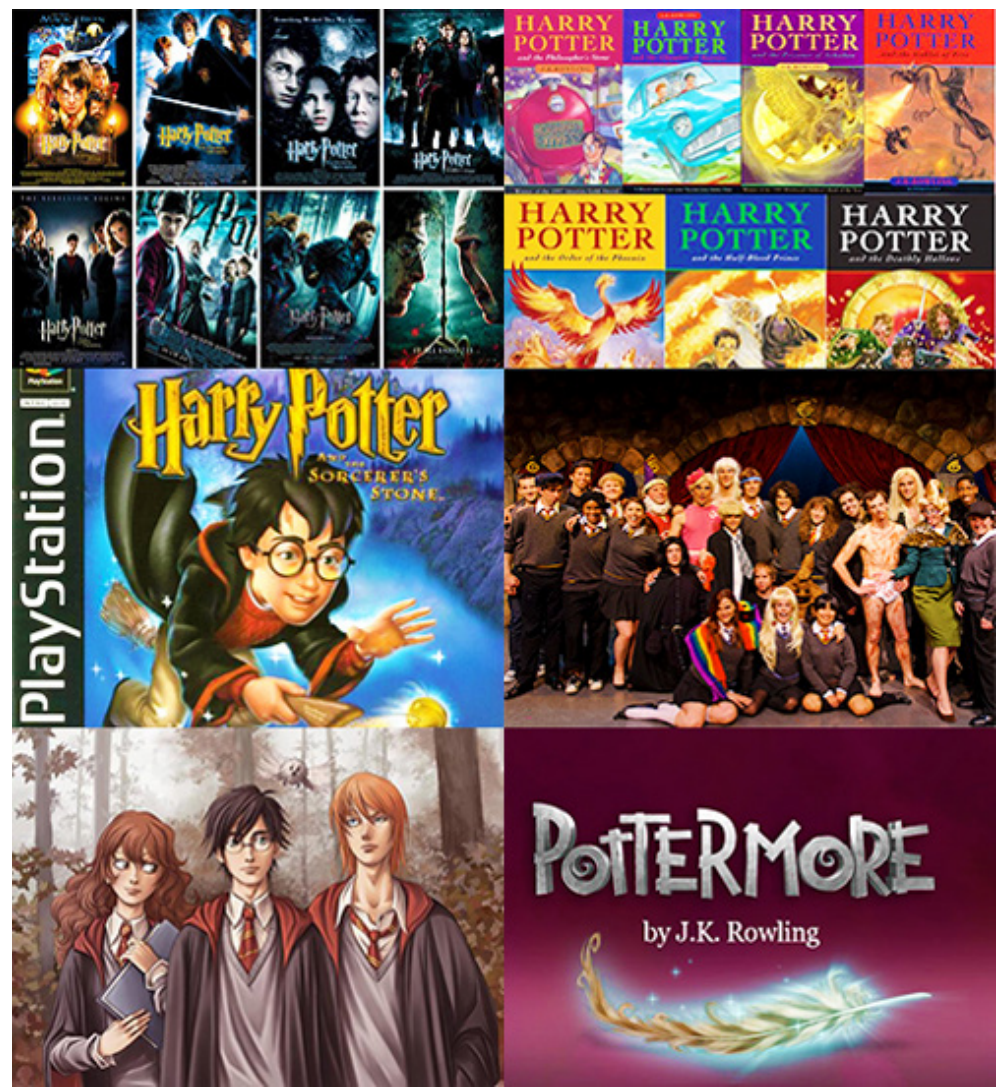

Görsel 2. Harry Potter Evreni

Harry Potter, yazar J.K. Rowling tarafından yaratılan, bir dizi fantezi roman üzerine şekillenen bir eserdir. Transmedya hikaye anlatımının başarılı örneklerinden biri olarak Harry Potter serisinin birçok alanda çeşitlilik sunan bir yapıya sahip olduğu söylenebilir. Seri kitaplarla ilk olarak piyasada yerini alan Harry Potter kitaptan uyarlama filmlerle yelpazesi genişletmiştir. Kitap ve filmlerin başarısının ardından video oyunlarıyla Harry Potter transmedya evreni daha da çeşitlenmiştir. Etkileşimi arttırmak ve hayran kitlesiyle bağları canlı tutmak için pottermore.com isimli bir web sitesi tasarlanmıştır. Hayranların hesap açabildiği, kitap, film ve oyunlar dışında daha derin hikayeleri keşfedebildiği ve kullanıcıların Hogwards evlerine girerek ödüllere ulaşmak için çeşitli sınavlara tabi tutulduğu bu organik siteyle insanların deneyimlerini geliştirmesi amaçlanmaktadır (Joell, 2018). Bu bağlamda sunmuş olduğu içerik unsurları bağlamında Harry Potter'ın çok sayıda metnin birleşiminden meydana gelen bir anlatı olduğunu belirtmek mümkündür. 
Tablo 2. Harry Potter evreninin transmedya hikaye anlatımındaki yedi prensibe göre değerlendirilmesi

\begin{tabular}{|c|c|}
\hline $\begin{array}{l}\text { Yayılabilirlik ve } \\
\text { Delinebilirlik }\end{array}$ & $\begin{array}{l}\text { Harry Potter serisi işleyiş olarak tüketici etkileşimini dikkate olan özellikleri } \\
\text { içinde barındırmaktadır. Tüketiciler ortaya konan medya içeriğiyle sosyal } \\
\text { ağlar ve dijital unsurlar aracılığıyla aktif olarak katııı sağlamaktadır. Farklı } \\
\text { uygulamalar aracılığıyla seyircinin derin bir deneyim kazandığı ve sürece } \\
\text { doğrudan katkı sağladığı söylenebilir. }\end{array}$ \\
\hline $\begin{array}{l}\text { Süreklilik ve } \\
\text { Çokluluk }\end{array}$ & $\begin{array}{l}\text { Harry Potter transmedya dünyasında işlenen konuların süreklilik ilkesi } \\
\text { bağlamında bir iç tutarlılık üzerine kurgulandığı görülmektedir. Çıkış noktası } \\
\text { bakımından kitaplara bağlı olarak sonradan organize edilen çalışmaların } \\
\text { temelde tek bir dizge üzerinden kendi iç dinamiklerini şekillendirdiği } \\
\text { söylenebilir. }\end{array}$ \\
\hline $\begin{array}{l}\text { Daldırma ve } \\
\text { Çıkartılabilirlik }\end{array}$ & $\begin{array}{l}\text { Harry Potter'da kullanıcı deneyimini arttırmak adına kurgusal dünyanın } \\
\text { daha derin bir bütünlükle tasarlandığını belirtmek mümkündür. Özellikle } \\
\text { sunulan video oyunlarla kullanıcıların daha geniş ve sürprize açık bir } \\
\text { hikaye örgüsü içerisinde kendilerini bulmaları söz konusudur. Ayrıca } \\
\text { derinlik ve çeşitlilik sağlamak için kullanıcıların farklı karakterlere bürünüp } \\
\text { oyun içerisinde bu şekilde ilerlemesi de mümkündür. }\end{array}$ \\
\hline Dünya İnşası & $\begin{array}{l}\text { Harry Potter evreninin çıkış noktası olan kitaplar ve sonrasında, filmler, video } \\
\text { oyunlar, interaktif web sitesi, sosyal medya kanalları, çizgi romanlar, viral } \\
\text { çalışmalar ve internet mağazası gibi geniş yelpazeli bir yapılanmayı içeren } \\
\text { uygulamalar yaratılan her hikayeyi farklı bir pencereden aktarmaktadır. } \\
\text { Karmaşık kurgusal dünyaya dahil olan kullanıcılar ve izleyiciler derinlere } \\
\text { dalmada farklı alternatiflere sahip olmaktadır. }\end{array}$ \\
\hline Dizisellik & $\begin{array}{l}\text { Harry Potter'da ortaya konan içerikler belirli bir dizisellik özelliğini } \\
\text { içinde barındırmaktadır. Hem kitap ve film gibi entegre ilerleyen medya } \\
\text { içeriklerinde hem de çizgi roman ve oyunlar gibi kendine has özelliklere } \\
\text { sahip olan uygulamalarda bütünlüğe katkı sağlamak adına yapıların } \\
\text { şekillendiği gözlenmektedir. }\end{array}$ \\
\hline Öznellik & $\begin{array}{l}\text { Harry Potter'da farklı çekicilikler gözetilerek içeriklerin çeşitlendirilmesi söz } \\
\text { konusudur. Örneğin kitap okumaktan hoşlanmayan veya vakti olmayan } \\
\text { tüketiciler için Pottermore web sitesi üzerinden hikayeye dahil olma fırsatı } \\
\text { sağlanmakta ve katılımcı kültür dinamikleri kullanılarak tüketiciler için } \\
\text { topluluk havası yaratılmaktadır. }\end{array}$ \\
\hline Performans & $\begin{array}{l}\text { Harry Potter'da tüketicilerin kullanıcı deneyimini yaşamaları ve sürece dahil } \\
\text { olmaları için etkileşimli kanallar aktif hale getirilmiştir. Özellikle YouTube'da } \\
\text { Harry Potter transmedya evrenini içeren farklı kanallarla etkileşimli bir ortam } \\
\text { yaratılmıştır. Kullanııların bu kanallar altında toplanması ve düşüncelerini } \\
\text { ifade etmesi teşvik edilmektedir. }\end{array}$ \\
\hline
\end{tabular}




\subsubsection{Star Wars}

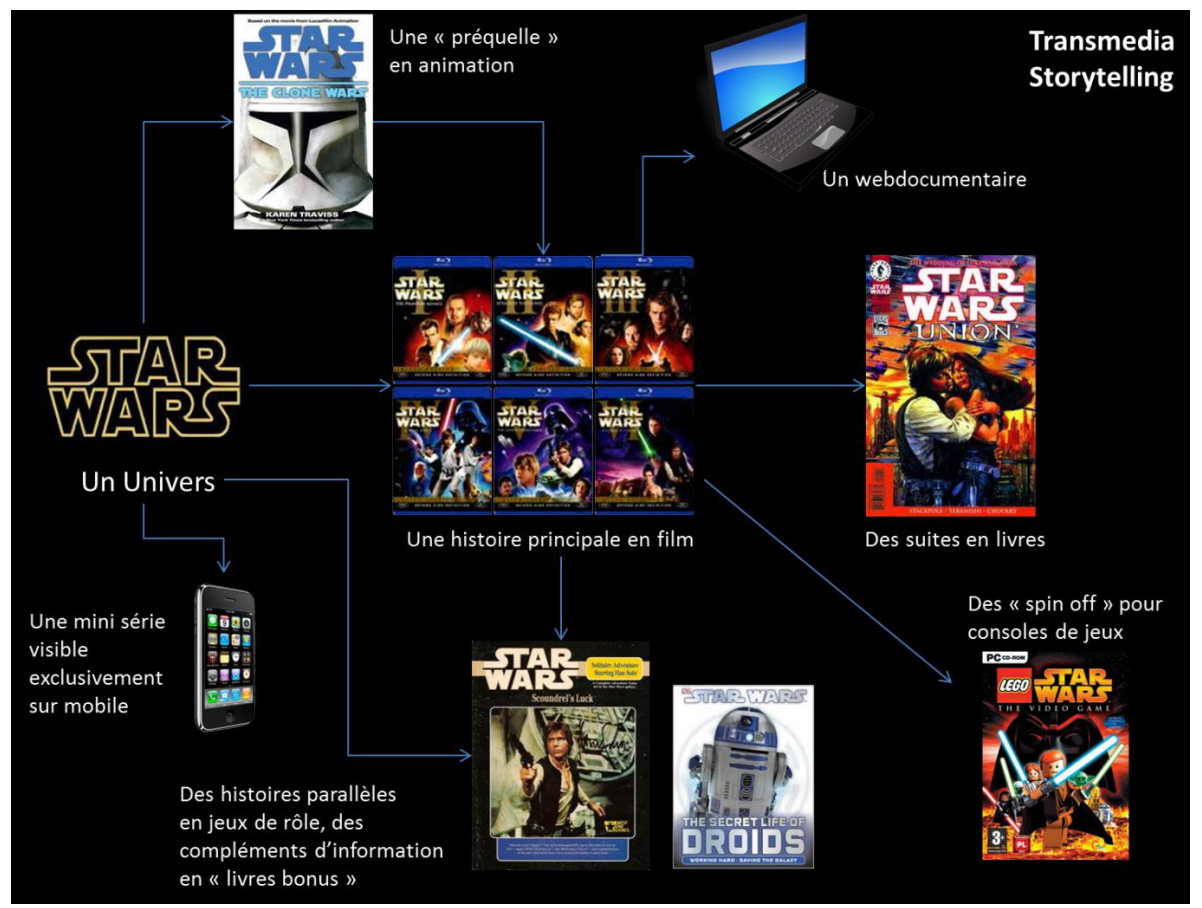

Görsel 3. Star Wars Evreni

Star Wars serisi 1977 yılında 'Star Wars: A New Hope' isimli filmle ilk kez izleyicilerle buluşmuştur. Star Wars üç kuşaktan beri (film, televizyon, kitap, oyun, çizgi roman, internet mağazası gibi) birçok uygulamanın işlevsel bir şekilde adapte edildiği önemli transmedya örneklerinden biridir. Transmedya öyküleri temel olarak, belirli bir metnin veya metin dizilerinin sınırlarının ötesine genişleyen zengin bir kurgusal dünyaya intiyaç duymaktadır. Modern medya şirketleri, bir dizi medya formunda ekonomik çıkarlara sahiptir. Bu bağlamda şirketlere geniş olanaklar sunan transmedya hikaye anlatımının sistemsel bir yapı olarak benimsenmiş olması son derece mantıklı gözükmektedir. Şöyle ki; medya platformları, bir anlatı yaymak için, herhangi bir metin üzerindeki geri dönüşlerini artırabilirler. Yani, Star Wars açısından, Walt Disney Studios Motion Pictures filmleri dağıtmakta; televizyon dizisi Star Wars: İsyancılar Disney XD kanalında yayın yapmakta; Star Wars çizgi roman (Disney'e ait) Marvel Comics tarafından dağıtıImakta; ve Star Wars karakterleri Disney Interactive Studios tarafından yayınlanan video oyunu Disney Infinity 3.0'da kullanılmaktadır (Wakeman, 2018). 
Tablo 3. Star Wars evreninin transmedya hikaye anlatımındaki yedi prensibe göre değerlendirilmesi

\begin{tabular}{|c|c|}
\hline $\begin{array}{l}\text { Yayılabilirlik ve } \\
\text { Delinebilirlik }\end{array}$ & $\begin{array}{l}\text { Star Wars genişletilmiş evreninde tüketici etkileşiminin sağlanması adına } \\
\text { dijital platformlarda ve sosyal ağ sitelerinde farklı uygulamaların gerçek } \\
\text { kılındığı görülmektedir. Kullanıcılarla doğrudan iletişimin tercih edildiği bu } \\
\text { platformlarda sürprizler ve filmlerle ilgili özgün paylaşımlar yapılmaktadır. }\end{array}$ \\
\hline $\begin{array}{l}\text { Süreklilik ve } \\
\text { Çokluluk }\end{array}$ & $\begin{array}{l}\text { Serinin ilk filminden itibaren Star Wars evreninin sürekli genişleyen ve } \\
\text { değişen bir yapıyı içerdiği söylenebilir. Bununla birlikte dijital dünyadaki } \\
\text { etkileşimli süreçleri içinde barındıran yeniliklerden önce tek yönlülük } \\
\text { iletişimin ana yapısını belirlemekteydi. Ancak teknolojide yaşanan } \\
\text { değişimler Star Wars'ta transmedya uygulamalarının çeşitlenmesini ve } \\
\text { kullanıcıların birer katılımcıya dönüşmesine etken olmuştur. }\end{array}$ \\
\hline $\begin{array}{l}\text { Daldırma ve } \\
\text { Çıkartılabilirlik }\end{array}$ & $\begin{array}{l}\text { Transmedya uygulamalarının karakteristik özelliklerinden biri ana hikayeyle } \\
\text { paralel olarak her hikaye örüntüsünde farklı gizemlerin sunulmasıdır. } \\
\text { Star Wars serisine bakıldığında farklı uygulamalarda hikaye derinliği } \\
\text { yakalanarak izleyici veya kullanıcılara merak çekiciliği üzerinden aktarımın } \\
\text { sağlandığı görülmektedir. }\end{array}$ \\
\hline Dünya İnşası & $\begin{array}{l}\text { Star Wars'ta her hikayenin kendine özgü unsurları barındırdığı söylenebilir. } \\
\text { Ancak temelde her bir parça hikayeyi tamamlayan bir özelliktedir. Özellikle } \\
\text { video oyunlarda karakterler ve hikaye dünyasına katkı bağlamında yeni } \\
\text { içerikler üzerinden farklı bir boyut ortaya konulmaktadır. }\end{array}$ \\
\hline Dizisellik & $\begin{array}{l}\text { Transmedya hikaye anlatımı doğası gereği dağınık ve karmaşıkbir yapıdadır. } \\
\text { Ancak bu karmaşık unsurların belirli bir düzen yansıttığı söylenebilir. Bu } \\
\text { durum aynı zamanda diziselliği de beraberinde getirmektedir. }\end{array}$ \\
\hline Öznellik & $\begin{array}{l}\text { Star Wars'ta kurgusal dünyanın içermediği keşfedilmemiş noktalara } \\
\text { odaklanmak mümkündür. Star Wars: The Clone Wars isimli animasyon } \\
\text { dizisi versiyonunda filmin çoğu kısmını içermeden kendi içinde bir hikaye } \\
\text { örgüsü yaratılması söz konusudur. }\end{array}$ \\
\hline Performans & $\begin{array}{l}\text { Star Wars'ta transmedya örgüsü tüketicileri teşvik etmeye yöneliktir. } \\
\text { Tüketiciler sadece bir filmi izlemek üzere bilet satın alma ya da sadece } \\
\text { vakit geçirmek için video oyununu oynamaktan öte hikayenin tamamını } \\
\text { hissetmek ve bir parçasına dönüşmek, sonrasında sosyal medyada ya } \\
\text { da çeşitli platformlarda Star Wars hakkında konuşmak için sürece dahil } \\
\text { olmaktadırlar. }\end{array}$ \\
\hline
\end{tabular}




\section{Sonuc}

Bilgi iletişim teknolojilerinde yaşanan gelişmeler, birçok alanda hızlı bir dönüşüm yaşanmasına neden olmaktadır. Web 2.0 olanaklarının bir çıktısı olarak iletişim çabalarının dijital ve etkileşimli ortamlarda hayat bulması bilginin eş zamanlı olarak paylaşılması ve yayılmasını mümkün hale getirmiştir. Tüketici yapısında gerçekleşen değişim markaların da hamlelerini çeşitlendirmelerini gerekli kılmaktadır. Bu bağlamda farklı medya biçimleri arasındaki ilişkiyi ifade eden transmedya, markaların iletişim olanaklarını arttırmalarında ve etkileşimli süreçler yaratarak kullanıcıları sürece dahil etmelerinde alternatif bir uygulama sunan iletişim çabalarından biridir.

Farklı medya platformları ve uygulamaları arasında organik bağ içeren ve bir çeşit yapısal ilişkiyi açıklayan transmedya, başlangıçta medya çeşitlemesi olarak addedilmesine rağmen günümüzde daha komplike bir yapıyı içeren, birbirine bağlantılı yapılar üzerinden çoklu hikaye örgüsüne dayanan çok parçalı hikaye anlatımını karşılamaktadır. Transmedya hikaye anlatımının mutlaka bir dizi kuramsal, felsefi ve yaratıcı yaklaşımı kapsaması gerekmektedir.

Araştırma kapsamında incelenen transmedya çalışmalarına bakıldığında örneklemi içeren üç evrenin de benzer pratikler bağlamında şekillendiği görülmektedir. Tüketicilerin derin bir deneyim kazanması üzerine kurulan ve sürece dahil olmalarına yönelik bileşenlerin ön planda olduğu bir yapılanmadan bahsetmek mümkündür. Dijital teknolojilerin insan yaşamına dahil olması ve gerçek zamanlı iletişime olan yönelimlerden kaynaklı olarak transmedya çalışmalarının tüketici etkileşimini dikkate alan özellikleri içinde barındırdığı söylenebilir. Çalışmaların tamamına bakıldığında parça hikayelerde ana çalışmadan farklı olarak bazı özgün içerikler yaratılmasına rağmen ana hikayeye uygun olarak çalışmaların tasarlandığı ve devam ettirildiği görülmektedir. Aynı zamanda yaratılan özgün içeriklerin kendi anlatım özelliklerinden beslendiğini belirtmek mümkündür. Süreklilik sağlamak ve derin bir deneyim pratiğini geniş bir zaman dilimine yaymak için çeşitlilik yaratan video oyunlarının tüketiciye sunulması söz konusudur. Bu noktada transmedya hikaye anlatımını güçlendirmek ve derinlik yaratmak adına kullanıcılara farklı karakterlere bürünüp oyun içerisinde ilerleme imkanının sağlandığı görülmektedir. Dinamik bir yapının yaratılması için geniş yelpazeli bir yapılanma felsefesinin özellikle Harry Potter evreninde daha yoğun olarak tercih edildiği söylenebilir. Filmler, oyunlar, interaktif web sitesi, kitap, internet mağazası, çizgi roman ve sosyal medya kanalları gibi çoklu medya içerikleriyle hikayelerin farklı pencerelerden aktarımı gerçekleştirilmiştir. Bu çoklu aktarımın temelinde ise karmaşık bir kurgusal dünyada tüketici ve katılımcıların kendilerini bulmaları yer almaktadır. Böylece tüketicinin farklı alternatifler üzerinden derinlere dalmayı gerçekleştirmesinin amaçlandığı söylenebilir. Örnekleme bakıldığında, hikaye örgüsünün kapsadığı sınırlar açısından farklı esneklikler taşıdığı görülmektedir. Örneğin, Matrix’te film üçlemesi ve diğer transmedya çalışmaları arasında uzun zaman farkı olmamasından dolayı sürekli genişleyen bir yapıdan bahsetmek mümkün değildir. Ancak Harry Potter ve özellikle Star Wars'ta yıllar içerisinde hem teknolojideki değişmeler hem de farklı medya uygulamalarındaki gelişmelerden dolayı sürekli genişleyen ve değişen bir 
yapının ortaya çıkması söz konusudur. Bu bağlamda transmedya hikaye çalışmasının sürdürülebilir kılınmasında ve çeşitlendirilmesinde ana hikayenin sahip olduğu temel özelliklerin anahtar bir rol oynadığını söylemek mümkündür.

\section{Kaynakça}

Ayten, A. (2014). Yöndeşme ve Gazetecilik. Müge Demir (Ed.). Yeni Medya Üzerine Vol. 2 (s.93121) içinde. Konya: Literatürk.

Bernstein, P. (2013). The 3 Rules of Transmedia Storytelling from Transmedia Guru Jeff Gomez, http://www.indiewire.com/2013/12/the-3-rules-of-transmedia-storytelling-from-transmedia-gurujeff-gomez-32325/

Borden, Z. (2010). http://www.scriptmag.com/features/transmedia-and-writing-starlight-runnergoes-the-distance, Erişim Tarihi: 25.05.2018

Brieger C (2013) Exploring New Communication Strategies for a Global Brand - Transmedia Storytelling and Gamification Dissertation, Norwegian School of Economics.

Castells, M. (2005). Ağ Toplumunun Yükselişi, Enformasyon Çağı: Ekonomi, Toplum ve Kültür. (Ebru Kılıç, çev.). Cilt:1. İstanbul: İstanbul Bilgi Üniversitesi Yayınları.

Claebe, H. ve Hancox, D. (2017). Transmedia storytelling, New York: Oxford University Press

Escobedo, J. (2017). Transmedia Will Shape The Future Of Hollywood And Fortune 500 Firms, https://www.forbes.com/sites/joeescobedo/2017/07/01/meet-the-man-behind-hollywood-andfortune-500-firms-transmedia-success/\#2157041e33da, Erişim Tarihi: 22.05.2018

Fiorelli, G. (2013). Transmedia Storytelling: Building Worlds For and With Fans, https://moz.com/ blog/transmedia-storytelling-building-worlds-for-and-with-fans, Erişim Tarihi: 10.10.2018

Heesvelde, E.V. (2000). Convergence between fixed and mobile communications. Info, Cilt: 2, Sayı: 3, ss. 271-275.

Jenkins, H. (2009). The Revenge of the Origami Unicorn: Seven Principles of Transmedia Storytelling (Well, Two Actually. Five More on Friday), http://henryjenkins.org/2009/12/the revenge_of_the_origami_uni.html, Erişim Tarihi: 27.09.2018

Jenkins, H. (2006). Convergene Culture, New York University Press: NewYork

Jenkins, H. (2003). Transmedia storytelling: Moving characters from books to films to video games can make them stronger and more compelling, Mit Technology Review, https://www. technologyreview.com/s/401760/transmedia-storytelling/, Erişim Tarihi: 02.10.2018

Jenkins, H (2001). Convergence? I Diverge. Technology Review, 104(5), 93.

Joell, C. (2018). Harry Potter Transmedia Storytelling, https://wordpress.susqu.edu/ engl390/2018/04/03/harry-potter-transmedia-storytelling/, Erişim Tarihi: 19.02.2019

Kırcova, I. ve Enginkaya, E. (2015). Sosyal Medya Pazarlaması. İstanbul: Beta Yayınları.

Plessis, C. (2018). Prosumer engagement through story-making in transmedia branding, International Journal of Cultural Studies, Cilt: 1, Sayı: 18.

Pratten, R. (2011). Getting Started in Transmedia Storytelling: A Practical Guide for Beginners, http://videoturundus.ee/transmedia.pdf, ISBN: 1456564684, Erişim Tarihi: 11.10.2018

Roper, P. (2014). Q\&A with Jeff Gomez on transmedia storytelling: what is it, and why should brands care?, https://www.marketingmag.com.au/hubs-c/qa-with-jeff-gomez-on-transmediastorytelling-what-is-it-and-why-should-brands-care/, Erişim Tarihi: 23.05.2018

Scolari, C. (2009). Transmedia storytelling: implicit consumers, narrative worlds, and branding in contemporary media production. International Journal of Communication, Sayı: 3, ss. 586-606. 
Wakeman, E. (2018). Transmedia storytelling with Star Wars, https://rtf.utexas.edu/news/ transmedia-storytelling-star-wars, Erişim Tarihi: 03.06.2018

Yıldırım, A. ve Şimşek, H. (2013), Sosyal Bilimlerde Nitel Araştırma Yöntemleri, (9. Baskı), Ankara: Seçkin Yayınları.

https://www.futurelearn.com/courses/transmedia-storytelling/0/steps/27374, Erişim Tarihi: 29.05.2018

http://convergencefa2016.blogspot.com/2016/11/while-multimedia-is-defined-asusing.html, Erişim Tarihi: 10.10.2018 